\title{
MANAGING A PORTFOLIO OF SUPPLIER RELATIONS IN INTERNET-DRIVEN ELECTRONIC MARKET PLACES.
}

A theoretical discussion

\author{
MARTIN GRIEGER, HERBERT KOTZAB and TAGE SKJØTT-LARSEN \\ Department of Operations Management, Copenhagen Business School, Denmark
}

\begin{abstract}
Corporative buying has changed from simple purchasing to e-sourcing, which means transforming the interaction between companies from transactional to relational relations. The following paper presents the conceptual framework of a supplier-buyer portfolio, when sourcing is done over the Internet. The perspective chosen is Supply Chain Management. Differing between three types of internet-driven electronic market places (private, consortia and independent e-market), different cooperative business relations have to be set up by supply management.
\end{abstract}

Key words: Cooperative business relationships, Internet-based electronic marketplaces, portfolio model

\section{PROBLEM}

\subsection{General introduction}

Supply Chain Management (SCM) can be defined as the management of an entire set of business processes that produces and delivers products/services to the final customer (e.g. Cooper et al. 1997). These business processes refer particularly to the management of the product and return flows, procurement, demand management and/or order fulfillment. The center of SCM's attention is the design of relationships amongst the supply chain members (Schary and Skjoett-Larsen 2001).

The original version of this chapter was revised: The copyright line was incorrect. This has been corrected. The Erratum to this chapter is available at DOI: 10.1007/978-0-387-35692-1_36 
Thereby, the Internet offers the supply chain new methods for streamlining the coordination within the supply chain. Leading firms have long recognized that one critical key success factor for SCM is e-dimension (e.g. Christopher 1998 or Lee 2000). A number of e-business models can therefore be used to erase cross-organizational boundaries between firms and their customers and/or suppliers.

One of these business models is the Internet-based electronic marketplace (IEMP), which we define for our purpose as a place on the Internet, where corporate (= business) buyers and suppliers (B2B) meet, trade, and collaborate. Most observers have assumed that IEMPs would come to dominate the B2B landscape. In combination with SCM, several authors mean that these two areas will contribute to the future success of companies and/or a network of companies (see e.g. Anderson and Lee 2000; Chaffey 2002; Nøkkentved 2000).

\subsection{Research purpose, research question and methodology}

At a first glance the two areas of SCM and IEMP might be contradictory, where SCM aims for collaboration, and IEMPs focuses on economic market transactions. But, concentrating at the procurement dimension of SCM, more and more companies buy their input factors over the Internet using IEMPs.

Consequently, we assume a further increasing of e-sourcing via IEMP within a supply chain and we expect procurement management to segment the vast number of existing IEMPs (see Grieger 2001) in a similar way as they differentiated their vendor base. While classical models focused on the volume of products purchased (ABC-model), more recent approaches refer to the evaluation of vendor relations (see e.g. Kraljic 1983, Cox 1996, Olsen and Ellram 1997, Bensaou 1999 or Helper 1993). In this manner, the successful management of strategic supplier relations was the research focus of their work.

Our research venture tries to answer the following question: How are IEMP's changing existing procurement management practices, which focused on the management of supplier relations.

Therefore, we will develop an IEMP-driven buyer-supplier relationshipportfolio, which can be applied to evaluate the attractiveness of any given IEMP for procurement applications. The purpose of the paper is to present our conceptual approach, which is part of an ongoing research project conducted at the Department of Operations Management at the Copenhagen Business School. The results of our research are based on an extensive 
electronic market places.

analysis of literature within the areas of supply chain management, buyersupplier relationships and IEMPs.

\section{GENERAL PRESENTATION OF THE RESEARCH CONSTRUCTS}

\subsection{Strategic character of procurement relations}

The procurement area is getting more and more strategic (see Schary and Skjoett-Larsen, 2001, 179). This is due to the transformation from transaction based purchasing to relationship oriented supply management. Helper (1993) characterized these strategies as "exit" (= arm's length relation) and "voice" (= obligational relation). However, assuming that a company has a huge vendor base (e.g. Wal-Mart has over 7,000 suppliers, see Kotzab 1997), a company will not manage all supplier relations the same.

Kraljic (1983) developed a product portfolio model based on the importance of purchasing and the complexity of the supply market. In his model the purchases are divided in four groups: Non-critical, leverage, bottleneck, and strategic products. While Kraljic focused on the power balance between the buyer and the supplier and proposed strategies based on the current power balance, Olsen \& Ellram (1997) recommended that the purchases were categorized based on the relative supplier attractiveness and the strength of the relationship between the buyer and the supplier.

Cox (1996) is segmenting supplier relationships by examining the degree of competence and the degree of asset specificity. His supplier relations ranged from adversarial leverage to strategic alliance. Low asset specificity skills should be outsourced through arm's length relations using competitive market signals. Skills of high asset specificity (core skills) should always be controlled through internal contracts. Skills of medium asset specificity should be based on various forms of collaboration spanning from preferred supplier to strategic supplier alliance.

Bensaou (1999) has proposed a portfolio model of supplier relationships based on specific investments by both buyers and suppliers. Bensaou classified buyer-supplier relationships into four categories depending on the degree of specific investments from either party: market exchange, buyer captive, supplier captive and strategic partnership. 
The idea behind any of these models was/is to manage the sourcing relationships in an economic way and as a consequence more and more companies have changed their sourcing strategies from multiple sourcing to single sourcing. Today, e-sourcing by using the various forms of IEMPs appears as an attractive alternative.

\subsection{Forms of Internet-driven Electronic Market Places}

We differ in our paper between three types of IEMPs, the independent, the private and the consortia IEMP.

Hundreds of entrepreneurs started independent IEMPs (also called dotcom-marketplaces) for a staggering variety of industries; from dairy farmers to casket makers. Few of these early pioneers have survived, and those that were able to sign up buyers and suppliers had trouble getting their members to do much buying online. Independent IEMPs provide at low costs an easy way to access a fragmented base of suppliers that are either difficult to reach, or are too numerous for companies to get their arms around. Independent IEMPs will find that their most favorable niches focus on low-risk trading activities, such as purchasing maintenance, repair and operations (MRO) goods and indirect materials. For example, Works.com focuses on trading MRO products. Similarly, ChemConnect trades commodity chemicals, thereby helping one of its largest customers, Dow Chemical, find new trading partners and make spot trades (Kalakota and Robinson 2000, Raisch 2001).

The early independent IEMPs faced numerous obstacles like they never got full support from key industry players (Wise and Morrison 2000). The independent IEMPs players ultimately failed to provide industries what they really needed in a $\mathrm{B} 2 \mathrm{~B}$ exchange - a way to automate current trading practices.

While these upstart marketplaces failed to gain support, leading players in key industries, such as General Motors and Boeing, believe in the benefits of the IEMPs. These giants have started, in their respective industries, to launch consortium IEMPs that address all the steps in the procurement process (Kalakota and Robinson 2000, Raisch 2001, Goldman Sachs 2000). Several consortium-led exchanges have gained attention. Transora, an exchange launched by 54 packaged-goods makers, plans to streamline every step in the supply chain, from purchasing raw materials to logistics, financing and insurance. Consortia IEMPs generally serve a medium-size or large and sometimes captive customer base, and thus might seek to become one-stop-shopping sources. Toward this end, many will develop MRO capabilities similar to independent IEMPs and form alliances with MRO- 

electronic market places.

focused independent IEMPs - as well as with other specialized service providers - that leverage the latter's established capabilities and relationships.

Most industry consortiums also will want to develop considerable direct materials procurement and exchange functionality (e.g., comparative catalogues for specific products across consortium members' entire supply base).

Nevertheless, some companies will insist on procuring direct materials through their own private IEMPs. Such was the case with Toyota and Volkswagen, which both chose to work directly with their own suppliers rather than to join Covisint. If more than a few companies in an industry take this position, the direct materials procurement functionality of industry consortiums will be limited. However, a certain amount of ground could be regained through "expertise positioning": becoming the hub for industry news, expert forums and industry-specific standards. About 200 consortium IEMPs are expected to endure in the long term - primarily those that provide shared-service platforms to industries (Goldman Sachs 2000). For most, the principal challenge will be to spearhead cooperation among traditional competitors and respond quickly to market changes.

With private IEMPs, companies build their own trading interface to both suppliers and customers via the Internet. The private IEMPs application acts as a platform for both buy side and sell side participants. With this "do it yourself' approach, companies can build their own network, with their enterprise at the center. Private IEMPs allow companies to trade in public marketplaces, but separate their organization from the inevitable changes in the public B2B industry. In addition, private IEMPs allow companies to maintain and improve relationships with their select partners and suppliers, providing faster ramp-up to manufacturing and more efficient and predictable inventory levels. Private IEMPs often also specialize in design and planning support and cover often tools needed to plan and manage complex projects or processes. Applications may range from a simple activity, such as designing a marketing brochure, to optimizing a transportation network between a consumer product manufacturer and its retailers (Kalakota and Robinson 2000, Raisch 2001).

Private IEMPs will focus primarily on direct materials procurement and deep collaboration with trading partners, which are the capabilities that deliver the highest tangible value to most companies. They will have the most sophisticated IEMPs capabilities, the most sophisticated software applications and the deepest integration with their trading partners' ERP systems. Because of their direct materials focus, they are less likely to stress MRO capabilities, nor will they emphasize industry news, industry data or 
expert forums (unless they are the dominant industry player-like Microsoft - that defines standards in a given marketplace).

\section{MEASURING THE EXTENT OF COOPERATIVE BUYER-SUPPLIER RELATIONSHIPS}

\subsection{Defining a cooperative business relationship in general}

Research has posited various definitions and determinants of cooperative business relationships and also developed certain theories to explain the reasons why firms enter such relationships. Researchers use a lot of other terms for "cooperative business relationships" such as "(strategic) partnerships", "strategic alliances" or "collaborative relationship" as opposed to the traditional "arm's length", "transactional" or "non-cooperative" type of associations (Ellram 1990, Ellram and Cooper 1990, Werani 2001).

Some people might argue that slightly differences or a hierarchical order exist between the various terms. So one can say that a strategic partnership might be the most cooperative business relationship. However, literature presents a specific set of determinants of when a business relationship can be seen as cooperative or partner-like. E.g. for Campbell (1985) a cooperative business relationship only exists, if both buyer and seller choose a cooperative interaction strategy.

General characteristics that distinguish between cooperative and noncooperative business relationships are long-term orientation (Heide and John 1990, Ganesan 1994 or Ellram 1990), relationship-specific investments (e.g. Tröndle 1987, Hallén, Johanson and Seined-Mohamed, 1991 or Håkansson and Snehota, 1995), frequency of interaction: Cooperative business relationships imply an intensive mutual coordination of partners, high degree of information sharing, seldom change of contact persons and mutual exchange of personnel between the partners (e.g. IMP Group 1982), asset specificity (Williamson 1985, Bensaou 1999, Cox 1996) and the adoption of norms (e.g. MacNeil 1980, Kaufman and Stern, 1988; Heide and John, 1992). 

electronic market places.

\subsection{Searching for a cooperative business relationship in an IEMP-setting}

Whether any IEMP need collaborative business relations or not might be due to following reasons (Anderson 2000, Nøkkentved, 2000, Kalakota and Robinson 2000, Raisch 2001):

- Data privacy: Many companies are not comfortable with the security and privacy levels of independent or consortium IEMPs. They also do not want to make their order patterns and prices visible to a third party. Private exchanges allow greater control over information.

- Functionality: By their nature, independent and consortium IEMPs must strive for functionality that serves a large variety of customers. For this reason, they are unlikely to implement the specialized functionality needed to support specialized inter-company trades or uniquely structured, collaborative relationships.

- Proprietary advantages: When an industry has only a few dominant players, those entities are more likely to build private exchanges to retain their competitive advantage. In other words, those leaders also are more likely to feel that aggregating purchasing volumes or sharing information disproportionately benefits their competitors.

- Avoidance of business risks: The liquidity and long-term success of many independent or consortium IEMPs is uncertain. Private exchanges give companies more control over their own risk.

Developing a set of general determinants to describe cooperative relationships for IEMP-sourcing strategies

The following table gives first an overview of specific determinants that describe a cooperative business relationship as found in the economic, marketing, organization and law literature.

These set of determinants, can also be used for building a buyer-supplier relationship portfolio in an IEMP-procurement setting, complete Campbell (1985) characteristics of a cooperative business relationship. Following Table 2 summarizes our determinants' operationalization. 


\section{HERBERT KOTZAB and TAGE SKJØTT-LARSEN}

\begin{tabular}{|c|c|c|}
\hline Determinants & Literature Source & Definitions \\
\hline Planning & $\begin{array}{l}\text { MacNeil (1978); } \\
\text { Noordewier, et al. (1990) }\end{array}$ & $\begin{array}{l}\text { Planning focuses on the process by which the } \\
\text { parties will continue the relationship; }\end{array}$ \\
\hline $\begin{array}{l}\text { Change of } \\
\text { Contact persons }\end{array}$ & IMP Group (1982) & $\begin{array}{l}\text { Relationships with relatively stable patterns } \\
\text { of social interaction with the consequence of } \\
\text { a lower degree of fluctuation of interaction } \\
\text { partners should be present }\end{array}$ \\
\hline Building trust & $\begin{array}{l}\text { Kasper-Fuehrer and } \\
\text { Ashkanasy (2001) }\end{array}$ & $\begin{array}{l}\text { Three issues are necessary to built trust in } \\
\text { interorganizational relationships: } \\
\text { Communication of trustworthiness by reliable } \\
\text { Information and Communication Tech- } \\
\text { nology, establishment of common business } \\
\text { understanding, and strong business ethics }\end{array}$ \\
\hline $\begin{array}{l}\text { Frequency of } \\
\text { interaction }\end{array}$ & Campbell (1985) & $\begin{array}{l}\text { Cooperative business relationships imply an } \\
\text { intensive mutual coordination of partners }\end{array}$ \\
\hline $\begin{array}{l}\text { Relationship- } \\
\text { specific } \\
\text { investments }\end{array}$ & $\begin{array}{l}\text { Hallén, Johanson and } \\
\text { Seined-Mohamed (1991); } \\
\text { Håkansson and Snehota } \\
\text { (1995); Tröndle (1987) }\end{array}$ & $\begin{array}{l}\text { Necessity of an efficient coordination of all } \\
\text { relationship activities. In this context, mutual } \\
\text { adaptations, which have to be considered as } \\
\text { relationship-specific investments are of } \\
\text { utmost importance. }\end{array}$ \\
\hline $\begin{array}{l}\text { Sharing of } \\
\text { Benefits and } \\
\text { burdens }\end{array}$ & $\begin{array}{l}\text { La Londe and Cooper } \\
\text { (1989); Ellram and } \\
\text { Cooper (1990); Gardner } \\
\text { and Cooper (1988) } \\
\end{array}$ & $\begin{array}{l}\text { Acceptance of short-term burdens in } \\
\text { expectation of longer benefits and burdens; } \\
\text { "futuristic orientation"; }\end{array}$ \\
\hline $\begin{array}{l}\text { Asset } \\
\text { Specificity }\end{array}$ & $\begin{array}{l}\text { Williamson (1985); } \\
\text { Bensaou (1999); Cox } \\
(1996)\end{array}$ & $\begin{array}{l}\text { The degree to which an asset is redeployable } \\
\text { or not }\end{array}$ \\
\hline Interdependence & Cummings (1984) & $\begin{array}{l}\text { The understanding that the loss of autonomy } \\
\text { will be compensated through expected gains; }\end{array}$ \\
\hline $\begin{array}{l}\text { (Operational-) } \\
\text { Information } \\
\text { sharing }\end{array}$ & $\begin{array}{l}\text { IMP (1982), Nøkkentved } \\
\text { (2000), MacNeil (1978); } \\
\text { Noordewier et al. (1990); } \\
\text { Gardner et al. (1994) }\end{array}$ & $\begin{array}{l}\text { Mutual sharing of relevant information, such } \\
\text { as orders, inventory status, production } \\
\text { schedules, promotions and sales forecasts }\end{array}$ \\
\hline $\begin{array}{l}\text { Knowledge } \\
\text { Sharing }\end{array}$ & $\begin{array}{l}\text { Howells and James } \\
(2000) ; \\
\text { Lee }(2000)\end{array}$ & $\begin{array}{l}\text { Recognition that relationship's knowledge } \\
\text { base is a valuable asset and that enlarging } \\
\text { that knowledge base and improving its use } \\
\text { can contribute to the competitiveness of the } \\
\text { whole supply chain }\end{array}$ \\
\hline $\begin{array}{l}\text { Computer } \\
\text { Linkages }\end{array}$ & $\begin{array}{l}\text { La Londe and Cooper } \\
\text { (1989); Lee (2000) }\end{array}$ & $\begin{array}{l}\text { Software compatible with supplier's/buyer's } \\
\text { system; } \\
\text { Shared (logistics) information system }\end{array}$ \\
\hline $\begin{array}{l}\text { Corporate } \\
\text { communication }\end{array}$ & $\begin{array}{l}\text { La Londe and Cooper } \\
\text { (1989); }\end{array}$ & $\begin{array}{l}\text { Frequent Face-to-face } \\
\text { planning/communication; High corporate } \\
\text { level of communication on important issues; } \\
\text { Many corporate levels of communication; }\end{array}$ \\
\hline Extendedness & $\begin{array}{l}\text { MacNeil (1978), (1980); } \\
\text { Noordewier et al. (1990); } \\
\text { Gardner et al. (1994); }\end{array}$ & $\begin{array}{l}\text { Part of ongoing relationship with no sharp } \\
\text { beginning and no clear endpoint, a long-term } \\
\text { open-ended relationship. }\end{array}$ \\
\hline
\end{tabular}

Table 1: Defining the determinants of a cooperative business relationship 
electronic market places.

\begin{tabular}{|c|c|}
\hline Determinants & Definitions \\
\hline Planning & $\begin{array}{l}\text { Planning integrates the operations of the two firms, smoothing the } \\
\text { disturbances from expected and unexpected environmental factors. } \\
\text { Specifically, planning focuses on the process by which the parties will } \\
\text { continue the relationship. Therefore, one can assume that planning } \\
\text { would lead to greater partnership satisfaction and future expectation of } \\
\text { partnership satisfaction. }\end{array}$ \\
\hline $\begin{array}{l}\text { Change of contact } \\
\text { persons }\end{array}$ & $\begin{array}{l}\text { Especially the IMP Group (1982) has called attention to the importance } \\
\text { of social interaction processes for the development of long-term } \\
\text { business relationships. Since, as already noticed, particularly } \\
\text { cooperative business relationships are expected to be based on long- } \\
\text { term orientation, in such relationships relatively stable patterns of social } \\
\text { interaction with the consequence of a lower degree of fluctuation of } \\
\text { interaction partners should be present. }\end{array}$ \\
\hline $\begin{array}{l}\text { Frequency of } \\
\text { interaction }\end{array}$ & $\begin{array}{l}\text { Cooperative business relationships imply an intensive mutual } \\
\text { coordination of partners }\end{array}$ \\
\hline $\begin{array}{l}\text { Relationship- } \\
\text { specific } \\
\text { investments }\end{array}$ & $\begin{array}{l}\text { The interdependence of partners in cooperative business relationships } \\
\text { (Tröndle 1987) points to the necessity of an efficient coordination of all } \\
\text { relationship activities. In this context, mutual adaptations, which have to } \\
\text { be considered as relationship-specific investments (Hallén, Johanson, } \\
\text { Seined-Mohamed, 1991; Håkansson, Snehota, 1995), are of utmost } \\
\text { importance }\end{array}$ \\
\hline $\begin{array}{l}\text { Sharing of } \\
\text { benefits and } \\
\text { burdens }\end{array}$ & $\begin{array}{l}\text { Sharing of benefits and burdens refers to the willingness of both parties } \\
\text { to accept short-term hardships with the expectation that the other party } \\
\text { will do the same. La Londe and Cooper (1989) uses the term win- } \\
\text { win/risk sharing. Specifically, it means acceptance of short-term } \\
\text { burdens in expectation of sharing future benefits and burdens. For } \\
\text { example, firms can reduce barriers to market entry by sharing burdens } \\
\text { and risks with a partner; in return both firms will share in future benefits } \\
\text { derived from entering the market. Thus, one can assume that this } \\
\text { dimension will increase partnership satisfaction. }\end{array}$ \\
\hline Asset specificity & $\begin{array}{l}\text { Asset specificity is the degree to which an asset can be put to alternative } \\
\text { uses. Assets used in the relationship that cannot easily be redeployed for } \\
\text { uses outside the partnership, are deemed assets specific to the } \\
\text { partnership. If the partnership already has a high degree of assets used } \\
\text { specifically for the partnership, then one expects a high level of } \\
\text { satisfaction with the partnership, since these assets cannot be easily put } \\
\text { to other uses. }\end{array}$ \\
\hline Interdependence & $\begin{array}{l}\text { As firms join forces to achieve mutually beneficial goals, they } \\
\text { acknowledge that each is dependent on the other. Interdependence } \\
\text { results from a relationship in which both firms perceive mutual benefits } \\
\text { from interacting and in which any loss of autonomy will be equitably } \\
\text { compensated through the expected gains. Thus, the willingness to give } \\
\text { up autonomy or control for the expectation of future gains is expected to } \\
\text { contribute to partnership satisfaction (Cummings, 1984). }\end{array}$ \\
\hline
\end{tabular}




\begin{tabular}{ll}
\hline $\begin{array}{l}\text { (Operational ) } \\
\text { information } \\
\text { exchange }\end{array}$ & $\begin{array}{l}\text { (Operational) information exchange refers to systems designed to } \\
\text { provide timely, accurate, and efficient information exchange. Systems } \\
\text { capable of accomplishing above, include electronic data interchange } \\
\text { (EDI) systems. One would expect firms to invest the capital and time in } \\
\text { operational information systems if they are satisfied with the } \\
\text { partnership. }\end{array}$ \\
\hline $\begin{array}{l}\text { Knowledge } \\
\text { sharing }\end{array}$ & $\begin{array}{l}\text { Knowledge sharing refers to the recognition that the partners'/supply } \\
\text { knowledge base and improving its use can contribute to the }\end{array}$ \\
& $\begin{array}{l}\text { competitiveness of the whole supply chain. Whilst much of the } \\
\text { management literature on organizational knowledge has focused on }\end{array}$ \\
& managing and measuring knowledge use within the firm, a number of \\
& studies have sought to explore how companies can access know-how \\
and experience from outside the organization and effectively import and \\
absorb that knowledge (Howells, James, 2000; Powell, 1998; Ruggles, \\
1998)
\end{tabular}

Table 2: Operationalizing the determinants of IEMP-driven cooperative business relationships

\section{DEVELOPING AN IEMP-DRIVEN BUYER- SUPPLIER RELATIONSHIP PORTFOLIO}

Based on our argumentation in the sections before, we present in Figure 1 our suggestion for a buyer-supplier relationship portfolio for IEMP-sourcing, where the $\mathrm{x}$-axis evaluates the business relationship based on our 
electronic market places.

determinants (see Table 3) and the y-axis refers to the number of IEMP participants (few, many; see Table 4). The model can be seen as an extension of the general proposal of Olsen and Ellram's "classical" purchasing relationship portfolio.

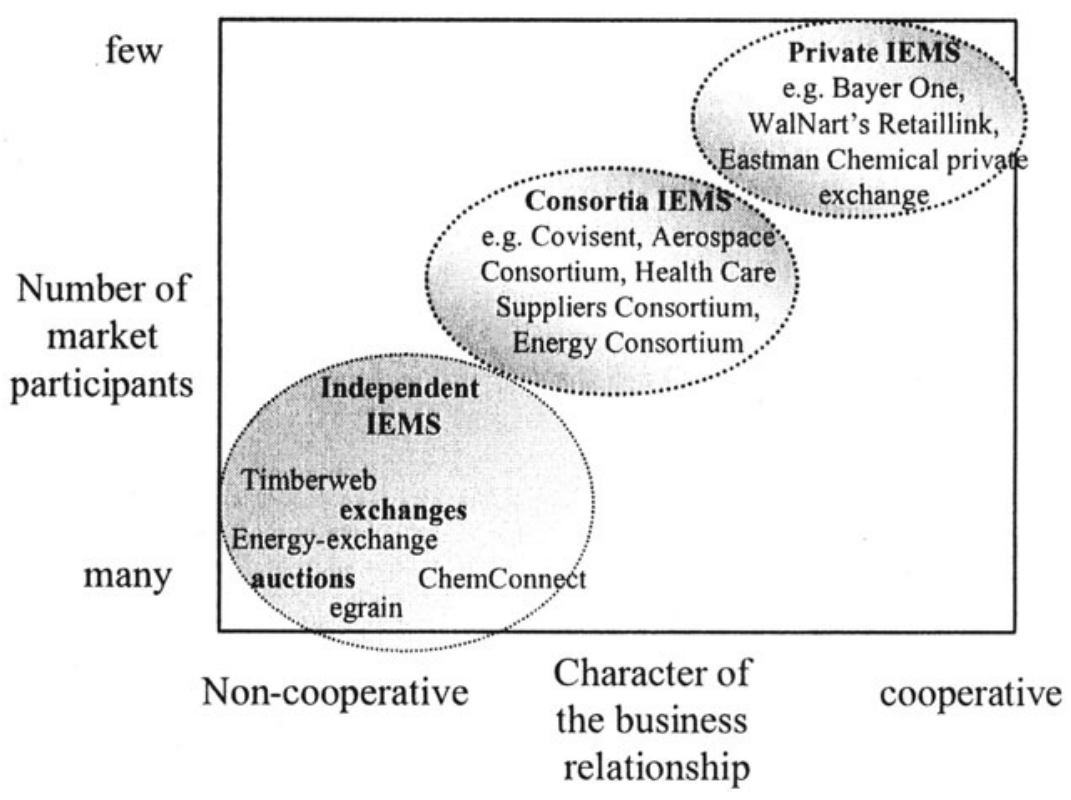

Figure 1. IEMPs portfolio model

While independent IEMPs provide a low cost and easy way to access a fragmented base of suppliers that are either difficult to reach, or are too numerous for companies to get an overview of (many-to-many structure), are the numbers of participants of consortia IEMPs smaller. The reason for this is that in consortia IEMPs, only a small group of large companies (few-tofew or few-to-many structure) combine their buying power, in which this few firms represent the highest concentration of market power (Kalakota and Robinson 2000). The consortiums provide an environment that compels buyers to purchase product by aggregating the industry's key suppliers and providing significant levels of product depth, breadth, selection, and service (Kalakota and Robinson 2000). Private IEMPs, on the other hand, allow 
companies to maintain and improve relationships with their own selected partners and suppliers (one-to-few structure) (see Table 4)

\begin{tabular}{|c|c|c|c|}
\hline \multirow[t]{2}{*}{ Determinants } & \multicolumn{3}{|c|}{ Market implications } \\
\hline & Private IEMP & Consortia IEMP & Independent IEMP \\
\hline Planning & Important & Limited/important & Less important \\
\hline $\begin{array}{l}\text { Change of contact } \\
\text { persons }\end{array}$ & Low & Limited & High \\
\hline $\begin{array}{l}\text { Frequency of } \\
\text { interaction }\end{array}$ & High & Medium & Low \\
\hline Trust building & Important & Important & Less important \\
\hline $\begin{array}{l}\text { Relationship- } \\
\text { specific } \\
\text { investments }\end{array}$ & High & High/Medium & Low \\
\hline $\begin{array}{l}\text { Sharing of benefits } \\
\text { and burdens }\end{array}$ & Yes & Limited & No \\
\hline Asset specificity & High & Medium & Low \\
\hline Interdependence & High & Medium & Low \\
\hline $\begin{array}{l}\text { Operational } \\
\text { information } \\
\text { exchange }\end{array}$ & High & High/Medium & Limited \\
\hline Knowledge sharing & High & Medium & No \\
\hline Computer linkages & $\begin{array}{l}\text { Hub-structure, } \\
\text { Internet with } \\
\text { firewalls } \\
\end{array}$ & Internet with firewalls & $\begin{array}{l}\text { "Open" system, } \\
\text { limited ERP } \\
\text { connectivity }\end{array}$ \\
\hline $\begin{array}{l}\text { Corporate } \\
\text { communication }\end{array}$ & High & Medium & Low \\
\hline Extendedness & Long-term & Long-term/short-term & Short-term \\
\hline
\end{tabular}

Table 3: Applying the determinants of cooperative business relationships to different forms of IEMPs

\begin{tabular}{l|l|l|l|}
\hline $\begin{array}{l}\text { Number of market } \\
\text { participants }\end{array}$ & \multicolumn{4}{|l|}{ Market implications } \\
\cline { 2 - 4 } & Private IEMP & Consortia IEMP & Independent IEMP \\
\hline Description & few & medium & many \\
\hline
\end{tabular}

Table 4: Determining the number of IEMP-participants

\section{DISCUSSION AND OUTLOOK}

Future SCM has to consider IEMPs as significant contributors to the overall supply chain success. The goal of our paper was to show, how IEMP 
might change the management of supplier relations. We assumed that supply chain managers would develop differentiated IEMP-driven supply chain strategies (procurement), which cooperative business relationship management is dependent on the type of IEMP.

For that reason, we developed an IEMP-driven buyer-supplierrelationships portfolio, which we discussed on a conceptual level. Our model was built upon general determinants of a cooperative business relationship, which we adapted for IEMP-issues. Based on three different types of IEMP's we could see that in the case of sourcing over a private IEMP, collaborative characteristics such as the frequency of interaction, trust building, high relationship specific investments and a sharing of benefits and burdens have to be recognized for a successful sourcing strategy.

In a next step, we have to validate our suggestion, which we plan to realize by a case study approach concentrating on

- an empirical identification of the determinants of cooperative buyersupplier relationships in an e-sourcing setting,

- an empirical analysis of their suitability and dependence towards our three IEMPs types (= independent, consortium and private IEMP) and

- the discovery of certain success criteria and limitations of e-based sourcing strategies, based on the different IEMPs types and their collaboration need.

\section{REFERENCES}

Anderson, D. L. (2000): New Supply Chain Business Models - The Opportunities and Challenges. www.ascet.com

Anderson, D. L. \& Lee, H. L. (2000): The Internet-Enabled Supply Chain: From the "First Click" to the "Last Mile". www.ascet.com

Bensaou, M. (1999): Portfolios of buyer-supplier relationships, Sloan Management Review 40,4 , pp. $35-44$

Campbell, N. C. G. (1985): An Interaction Approach to Organizational Buying Behavior. Journal of Business Research 13, pp. 35-48.

Chaffey, D. (2002): E-Business and E-Commerce Management. Prentice Hall.

Christopher, M. (1998): Logistics and Supply Chain Management. Strategies for Reducing Cost and Improving Service. Financial Times, Prentice Hall. Second Edition. London, New York, San Francisco etc.

Cooper, M., Lambert, D. and Pagh, J. (1997): Supply Chain Management: More than a new Name for Logistics, International Journal of Logistics Management 8, 1, pp. 1 - 14.

Cox, A. (1996): Relational competence and strategic procurement management. European Journal of Purchasing and Supply Management 2, 1, pp. 57-70

Cummings, T. (1990): Transorganizational Development. Research in Organizational Behaviour 6, pp. 367-422. 
Ellram, L. M. (1990): A Managerial Guideline for the Development and Implementation of Purchasing Partnerships. International Journal of Purchasing and Materials Management 27,3, pp. 2-8.

Ellram, L. M. \& Cooper, M. C. (1990): Supply Chain Management, Partnerships, and the Shipper-Third Party Relationship. International Journal of Logistics Management 1, 2, pp. $1-10$.

Ganesan, S. (1994): Determinants of Long-Term Orientation in Buyer-Seller Relationships. Journal of Marketing 58 (April), pp. 1-19.

Gardner, J. T. \& Cooper, M. C. (1988): Elements of Partnership. In: Joseph E. McKeon (ed.), Partnerships: A Natural Evolution in Logistics Relationships. Cleveland: Logistics Resource Forum.

Gardner, J. T., Cooper, M. C. \& Noordewier, T. (1994): Understanding Shipper-Carrier and Shipper-Warehouser Relationships: Partnerships Revisited. Journal of Business Logistics 16, 2, pp. 121-143.

Goldman Sachs (2000): Internet: B2B e-Commerce. The consortium report. Global Equity Research https://www.gs.com.

Grieger, M. (2001): Electronic Marketplaces - An Overview and A Call For Supply Chain Management Research. Proceedings of the Nordic Logistics Conference (Nofoma) in Island.

Hallén, L., Johanson, J. \& Seined-Mohamed, N. (1991): Interfirm Adaptations in Business Relationships, Journal of Marketing 55 (April), pp. 29.37.

Heide, J.B. \& John, G. (1990): Alliances in Industrial Purchasing: The Determinants of Joint Action in Buyer-Supplier Relationship. Journal of Marketing Research 27, pp. 24-36.

Heide J.B. \& John G. (1992): Do Norms Matter in Marketing Relationships? Journal of Marketing, 56, April, pp. 32-44

Helper, S. (1993): An exit-voice analysis of supplier relations. The case of the US automobile industry. In Grabher, G. (ed.), The Embedded Firm. On the Socioeconomics of Industrial Networks, Routledge, London, pp. 141-160.

Howells, J. \& James, A. D. (2000): Corporate Decision-Making on the Sourcing of Technological Knowledge. Paper presented to 'Knowledge Management: Controversies and their Causes' Conference, University of Warwick, Coventry, UK, 10-11 Feb. 2000.

Håkansson, H. \& Snehota, I. (1995): Developing Relationships in Business Networks, London, New York: Rout ledge

IMP Group (1982): An Interaction Approach. In: Håkansson, H. (ed.), International Marketing and Purchasing of Industrial Goods: An Interaction Approach. Chichester: Wiley, pp. 10-27.

Kasper-Fuehrer, E.C. \& Ashkanasy, N.M. (2001), Communicating trustworthiness and building trust in interorganizational virtual organizations. Journal of Management, 27, pp. 235-254.

Kaufman P.J. \& Stern L.W. (1992): Relational Exchange, Contracting Norms, and Conflict in Industrial Exchange, Advances in Distribution Channel Research, 1, pp. 135-159.

Kalakota, R. \& Robinson, M. (2000): e-Business 2.0 - Roadmap for Success. Addison Wesley, Bosten, San Francisco etc.

Kotzab, H. (1997): Neue Konzepte der Distributionslogistik von Handelsunternehmen, Wiesbaden

Kraljic, P. (1983): Purchasing must become Supply Management. Harvard Business Review, 61, pp. 109-117. 
LaLonde, B. J. \& Cooper, M. (1989): Partnerships in Providing Customer Service: A Third Party Perspective. Oak Brook, III: Council of Logistics Management.

Lee, H. (2000): Creating Value through Supply Chain Integration. Supply Chain Management Review, Sept./Oct.

MacNeil, I., R. (1978): Contracts: Adjustments of Long-term Relations Under Classical, Neoclassical and Relational Contract Law. Northwestern University Law Review 72, pp. 854-905.

MacNeil, I.R. (1980): The New Social Contract: An Inquiry into Modern Contractual Relations, Yale University Press, New Haven.

Noordewier, T., John, G. \& Nevin, J. (1990): Performance of Purchasing Arrangements in Industrial Buyer-Vendor Relationships. Journal of Marketing 54, October, pp. 80-93.

Olsen, R. F. \& Ellram, L., M. (1997): A Portfolio approach to Supplier relationships. Industrial Marketing Management 26, pp. 101-113.

Nøkkentved, C. (2000): Collaborative Processes in e-Supply Networks - Towards Collaborative Community B2B Marketplaces. Research Report. PricewaterhouseCoopers.

Olsen, R. F. and L. M. Ellram (1997) A Portfolio Approach to Supplier Relationships, Industrial Marketing Management, 26, 2, pp. 101-113.

Powell, W.W. (1998): Learning from collaboration. California Management Review 40, 22840.

Raisch, W. D. (2001): The eMarketplace - Strategies for Success in B2B eCommerce. McGraw-Hill, New York.

Ruggles, R. (1998): The state of the notion: knowledge management in practice. California Management Review, 40, 3.

Schary, P.B. and Skjoett-Larsen, T. (2001): Managing the Global Supply Chain. CBS Press, Copenhagen.

Tröndle, D. (1987): Kooperationsmanagement - Steuerung interaktioneller Prozesse bei Unternehmenskooperationen, Bergisch Gladbach, Köln: Eul.

Werani, T. (2001): On the Value of Cooperative Buyer-Seller Relationships in Industrial Markets. ISBM Report 2-2001. Institute for the Study of Business Markets. The Pennsylvania State University.

Williamson, O. E. (1985): The Economic Institutions of Capitalism. New York: Free Press.

Wise, R. \& Morrison, D. (2000): Beyond the Exchange - The Future of B2B. Harvard Business Review, Nov.-Dec., pp. 86-96. 